\title{
Olanzapine Increases RGS7 Protein Expression via Stimulation of the Janus Tyrosine Kinase-Signal Transducer and Activator of Transcription Signaling Cascade
}

\author{
Rakesh K. Singh, Ju Shi, Bozena W. Zemaitaitis, and Nancy A. Muma \\ Department of Pharmacology and Experimental Therapeutics, Loyola University Chicago, Stritch School of Medicine, \\ Maywood, Illinois
}

Received January 26, 2007; accepted March 27, 2007

\begin{abstract}
Atypical antipsychotics such as olanzapine have high affinity for multiple monoamine neurotransmitter receptors and are the mainstay of pharmacological therapy for treatment of schizophrenia. In addition to blocking monoamine receptors, these drugs also affect intracellular signaling cascades. We now report that 24-h treatment with $300 \mathrm{nM}$ olanzapine causes desensitization of serotonin $(5-\mathrm{HT})_{2 \mathrm{~A}}$ receptors in $\mathrm{A} 1 \mathrm{~A} 1 \mathrm{v}$ cells, a rat cortical cell line, as indicated by a reduction in inositol phosphate accumulation following stimulation with a $5-\mathrm{HT}_{2 \mathrm{~A} / 2 \mathrm{C}}$ receptor agonist (-)-1-(2,5-dimethoxy-4-lodophenyl)-2-aminopropane $\mathrm{HCl}$. Olanzapine treatment for $24 \mathrm{~h}$ increased the levels of $5-\mathrm{HT}_{2 \mathrm{~A}}$ receptors in both cytosol $(234 \pm 34 \%$ of control level) and membrane fractions (206 $\pm 14 \%$ of control levels) and RGS7 proteins in both cytosol (193 $\pm 32 \%$ of control levels) and membrane fractions (160 $\pm 18 \%$ of control levels) as measured on Western blots. Increased phosphorylation of Janus tyrosine kinase (JAK) 2 and increased phosphor-
\end{abstract}

ylation and nuclear translocation of signal transducer and activator of transcription (STAT) 3 with 24-h olanzapine treatment demonstrate activation of the JAK-STAT signaling cascade. Pretreatment with a JAK inhibitor, AG490 [ $\alpha$-cyano-(3,4-dihydroxy)- $N$-benzylcinnamide], prevented the olanzapine-induced increase in membrane RGS7 protein levels; AG490 alone had no effect on RGS7 protein levels. We verified that treatment with AG490 reduced phosphorylation of JAK2 and inhibited the nuclear localization of phospho-STAT3. Interestingly, treatment with the JAK inhibitor had no effect on $5-\mathrm{HT}_{2 \mathrm{~A}}$ receptor protein levels. These data suggest that olanzapine-induced activation of the JAK-STAT signaling cascade causes increased expression of RGS7 protein, which in turn could mediate desensitization of $5-\mathrm{HT}_{2 \mathrm{~A}}$ receptor signaling caused by olanzapine because RGS7 binds to $\mathrm{G} \alpha_{\mathrm{q}}$ protein and accelerates GTP hydrolysis.
Atypical antipsychotics are widely prescribed for the treatment of schizophrenia. They are classified as atypical because of their ability to achieve antipsychotic effects with lower rates of extrapyramidal side effects compared with first generation antipsychotics such as haloperidol. In addition, selected atypical antipsychotics also improve certain aspects of cognitive function in schizophrenic patients, whereas typical antipsychotics may worsen cognition (Meltzer et al., 1999). Atypical antipsychotics improved side effects, and efficacy has been attributed to the high-affinity interaction with $5-\mathrm{HT}_{2 \mathrm{~A}}$ receptors (Kasper et al., 1999). Atypical anti-

This study was supported by United States Public Health Service Grant MH068612.

Article, publication date, and citation information can be found at http://jpet.aspetjournals.org.

doi:10.1124/jpet.107.120386. psychotics have also been shown to block other $5-\mathrm{HT}_{2}$ receptor subtypes, mainly $5-\mathrm{HT}_{2 \mathrm{~B}}$ and $5-\mathrm{HT}_{2 \mathrm{C}}$ (Lucaites et al., 1996). However, only $5-\mathrm{HT}_{2 \mathrm{C}}$ receptor antagonism is suggested in contributing to the atypical antipsychotic effects (Herrick-Davis et al., 2000; Rauser et al., 2001).

The $5-\mathrm{HT}_{2 \mathrm{~A}}$ receptor subtype has been implicated in various psychiatric disorders including depression, anxiety, and schizophrenia (Glennon et al., 1984). Olanzapine is an atypical antipsychotic, approved for the treatment of schizophrenia and bipolar disorder. Olanzapine has been also studied in the treatment of disorders such as substance abuse, aggression/violence, borderline personality disorder, and obsessivecompulsive disorder (Littrell et al., 2006).

Atypical antipsychotics as well as a specific 5- $\mathrm{HT}_{2 \mathrm{~A}}$ receptor antagonist, MDL 100,907, desensitize 5-HT $2 \mathrm{~A}$-mediated responses (Willins et al., 1999). However, the molecular

ABBREVIATIONS: 5-HT, serotonin; MDL 100,907, (+)- $\alpha$-(2,3-dimethoxyphenyl)-1-[2-(4-fluorophenylethyl)]-4-piperidinemethanol; ERK, extracellular receptor kinase; JAK, Janus tyrosine kinase; STAT, signal transducers and activators of transcription; RGS, regulator of G protein signaling; AG490, $\alpha$-cyano-(3,4-dihydroxy)- $N$-benzylcinnamide; DOI, (-)-1-(2,5-dimethoxy-4-lodophenyl)-2-aminopropane HCl; PBS, phosphate-buffered saline; IP, inositol phosphate. 
mechanisms involved in antagonist-induced desensitization of $5-\mathrm{HT}_{2 \mathrm{~A}}$ receptor signaling are not well understood. By understanding the molecular mechanisms underlying the effects of olanzapine and other atypical antipsychotics, we hope to gain insight into targets for therapeutic treatment of psychiatric disorders. It has been recently reported that olanzapine increases extracellular receptor kinase (ERK) 1/2 phosphorylation in rat prefrontal cortex (Fumagalli et al., 2006). Furthermore, changes in mRNA levels of both $5-\mathrm{HT}_{2 \mathrm{~A} / 2 \mathrm{C}}$ receptors with $5-\mathrm{HT}_{2 \mathrm{~A}}$ receptor antagonists after both chronic and short-term treatments have been reported (Buckland et al., 1997). These studies suggest that atypical antipsychotics may target intracellular pathways shuttling information from the receptor to the nucleus.

The Janus tyrosine kinase (JAK)-signal transducer and activator of transcription (STAT) signaling cascade has been reported to couple with $5-\mathrm{HT}_{2 \mathrm{~A}}$ receptors in skeletal muscles and vascular smooth muscle cells (Guillet-Deniau et al., 1997; Banes et al., 2005). G protein-coupled receptor agonists, thrombin and angiotensin II, have previously been shown to activate the JAK-STAT signaling cascade (Bhat et al., 1994). JAK-STAT could be one of the possible signaling pathways involved in mediating olanzapine-induced receptor desensitization. JAKs are a small family of cytoplasmic tyrosine kinases initially identified as a mediator of cytokine receptor signaling (Ihle, 1995). Agonist stimulation of cytokine receptors causes phosphorylation of JAK, which in turn phosphorylates tyrosine residues on the receptor cytoplasmic tail, facilitating activation of specific STATs. Tyrosine phosphorylates STAT, then undergoes dimerization and translocates to the nucleus, where it binds to target DNA sequences (Darnell, 1997).

Alterations in proximal components of the $5-\mathrm{HT}_{2 \mathrm{~A}}$ receptor signaling system could mediate desensitization in response to increased activity of intracellular cascades such as JAKSTAT. 5-HT ${ }_{2 \mathrm{~A}}$ receptors are classically linked to the $\mathrm{G} \alpha_{\mathrm{q} / 11}$ protein family (Ivins and Molinoff, 1990). Activation of $\mathrm{G} \alpha_{\mathrm{q} / 11}$ stimulates phospholipase $\mathrm{C}$ activity, which subsequently promotes the release of diacylglycerol and inositol triphosphate, which in turn stimulate protein kinase $\mathrm{C}$ activity and calcium release (Berg et al., 2001). It has been extensively reported that increased expression of regulator of $\mathrm{G}$ protein signaling (RGS) proteins cause desensitization of several $G$ protein-associated receptor systems (Koelle and Horvitz, 1996). RGS proteins reduce the duration of signaling of many $\mathrm{G}$ protein-coupled receptors by their action as GTPases, accelerating the hydrolysis of GTP-bound $\mathrm{G} \alpha$ proteins or by blocking the interaction of $\mathrm{G} \alpha$ with its target proteins through a not well understood process known as effector antagonism (Roy et al., 2006).

Expression of RGS7 protein in rat frontal cortex is well documented (Zhang and Simonds, 2000; Krumins et al., 2004) and decreased $5-\mathrm{HT}_{2 \mathrm{~A}}$ receptor-mediated signaling via direct interaction of RGS7 protein with $\mathrm{G} \alpha_{\mathrm{q}}$ has been widely characterized in different systems (DiBello et al., 1998; Ghavami et al., 2004). We hypothesize that the increased expression of RGS7 protein by the JAK-STAT signaling cascade contributes to olanzapine-induced desensitization of $5-\mathrm{HT}_{2 \mathrm{~A}}$ receptor signaling. In this study, we examined $5-\mathrm{HT}_{2 \mathrm{~A}}$ receptor and RGS7 protein levels in response to treatment with olanzapine and determined whether changes in these pro- teins are mediated by olanzapine-induced JAK-STAT signaling in A1A1v cells.

\section{Materials and Methods}

Cell Culture. A1A1v cells, a cortical cell line that expresses $5-\mathrm{HT}_{2 \mathrm{~A}}$ receptors, were used for all experiments and were generously donated by Dr. William Clarke and Kelly Berg (University of Texas Health Science Center, San Antonio, TX). Cells were grown in Dulbecco's modified Eagle's medium supplemented with $10 \%$ fetal bovine serum. Serotonin was removed from serum by filtration after treating with charcoal. Cells were grown in the serotonin-free serum media $24 \mathrm{~h}$ before treatment with olanzapine. Olanzapine was a generous gift from Eli Lilly \& Co. (Indianapolis, IN). The treatment concentration $(300 \mathrm{nM})$ was obtained by dissolving olanzapine in $20 \%$ acetic acid. The $\mathrm{pH}$ of the vehicle and olanzapine was adjusted to 6.5 with $10 \mathrm{~N} \mathrm{NaOH}$. A JAK inhibitor, AG490, was purchased from Calbiochem (San Diego, CA). It was reconstituted with dimethyl sulfoxide to obtain the desired concentration. (-)-1-(2,5-Dimethoxy4-lodophenyl)-2-aminopropane $\mathrm{HCl}$ (DOI) was purchased from Sigma-Aldrich (St. Louis, MO). Hanks' balanced salt solution mix (1X Hanks' balanced salt solution, $20 \mathrm{mM} \mathrm{LiCl}_{2}$, and $20 \mathrm{mM} \mathrm{HEPES}$ ) was used to dissolve DOI. Cells were treated with either vehicle (20\% acetic acid) or $300 \mathrm{nM}$ olanzapine for $24 \mathrm{~h}$ for various experiments.

Cell Fractionation. Cells were separated into membrane and cytosol fractions using ultracentrifugation as described previously (Tucker, 2004). In brief, cells were collected in hypotonic buffer containing $0.25 \mathrm{M}$ sucrose, $50 \mathrm{mM}$ Tris- $\mathrm{HCl}, 5 \mathrm{mM}$ EDTA, and protease inhibitor cocktail (Sigma-Aldrich). Cell homogenate was prepared by sonication three times for $10 \mathrm{~s}$. The homogenate was spun at $100,000 \mathrm{~g}$ for $45 \mathrm{~min}$ at $4^{\circ} \mathrm{C}$ to produce a pellet, which is composed of membrane fraction and a supernatant, which is the cytosol fraction. The pellet was reconstituted with hypotonic buffer. The protein amount was assessed with bicinchoninic acid protein assay kit (Pierce Chemical, Rockford, IL). Cytosolic and nuclear fractions were prepared as described previously (Andrews and Faller, 1991) with some modification. In brief, cells were washed and scrapped into ice-cold PBS containing phosphatase inhibitors. The pellet was collected after centrifugation at $1000 \mathrm{~g}$ for $1 \mathrm{~min}$ and resuspended into buffer A (10 mM HEPES-KOH, pH 7.9, $1.5 \mathrm{mM}$ $\mathrm{MgCl} 2,10 \mathrm{mM} \mathrm{KCl}, 0.5 \mathrm{mM}$ dithiothreitol, and protease inhibitor cocktail) and incubated for $10 \mathrm{~min}$ on ice followed by vortex mixing for $10 \mathrm{~s}$. The supernatant contains the cytosolic fraction. The pellet was resuspended in buffer B (10 mM HEPES-KOH, $\mathrm{pH} \mathrm{7.9,} \mathrm{25 \%}$ glycerol, $420 \mathrm{mM} \mathrm{NaCl}, 0.2 \mathrm{mM}$ EDTA, $1.5 \mathrm{mM} \mathrm{MgCl}_{2}, 10 \mathrm{mM} \mathrm{KCl}$, $0.5 \mathrm{mM}$ dithiothreitol, and protease inhibitor cocktail) and incubated on ice for $20 \mathrm{~min}$. The nuclear fraction was obtained as the supernatant after centrifugation at 18,000g for $2 \mathrm{~min}$.

Western Analyses. Equal amounts of protein were separated and transferred to nitrocellulose membrane as described previously (Shi et al., 2007). Membranes were blocked either in Tris-buffered saline or PBS containing $5 \%(\mathrm{w} / \mathrm{v})$ nonfat dry milk with $0.1 \%$ Tween 20 . The following primary antibodies were used: anti-RGS7 (1:1000, polyclonal antibody; Upstate Biotechnology, Inc., Lake Placid, NY), antiphospho-JAK2 (1:1000, polyclonal antibody; Affinity Bioreagents, Golden, CO), and anti-Jak2 (1:2000, polyclonal antibody; Upstate Biotechnology, Inc.). The anti-phospho-STAT1, STAT3, and STAT5 (1:1000, polyclonal antibodies) and anti-STAT1, STAT3, and STAT5 (1:1000, polyclonal antibody) were purchased from Cell Signaling (Danvers, MA). A monoclonal anti-actin antibody was from MP Biomedicals (1:10,000; Aurora, OH). Before incubation with a second primary antibody, blots were stripped with Restore Western blot stripping buffer (Pierce Chemical) by incubating at $37^{\circ} \mathrm{C}$ for $25 \mathrm{~min}$. After incubation blots were removed from stripping buffer, washed three times for 10 min each with Tris-buffered saline or PBS containing $0.1 \%$ Tween 20, and blocked again. Protein bands were analyzed densitometrically using Scion Image software (Scion Corporation, Frederick, MD). The integrated optical density for the film 
background was subtracted from the integrated optical density for each band. Each sample was measured in triplicate. RGS7 protein and $5-\mathrm{HT}_{2 \mathrm{~A}}$ receptor protein levels were normalized to actin protein used as a loading control, and phosphoproteins were normalized to the corresponding total protein levels. Protein levels from olanzapine-treated cells were normalized to vehicle-treated cells.

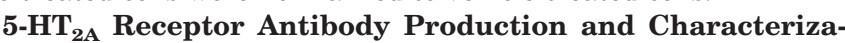
tion. A peptide corresponding to amino acids 22 to 41 of the rat $5-\mathrm{HT}_{2 \mathrm{~A}}$ receptor $\left(\mathrm{NH}_{2}\right.$-GD PRLYHNDFNSRDANTSE-OH) was synthesized and used to produce antibodies by Biosynthesis, Inc. (Lewisville, TX). This sequence is $85 \%$ identical to the mouse $5-\mathrm{HT}_{2 \mathrm{~A}}$ receptor sequence and $65 \%$ identical to the human $5-\mathrm{HT}_{2 \mathrm{~A}}$ receptor sequence as determined using the NCBI Sequence Viewer. The same peptide sequence was used previously by Garlow et al. (1993) to produce antibodies against the $5-\mathrm{HT}_{2 \mathrm{~A}}$ receptor. The antibodies produced were characterized using Western blotting and enzyme-linked immunosorbent assays. The antibody titer reported by Biosynthesis, Inc. was up to $1: 25,600$. A1A1v cells were used to verify the specificity of the $5-\mathrm{HT}_{2 \mathrm{~A}}$ receptor antibodies. Cells were transfected with the human $5-\mathrm{HT}_{2 \mathrm{~A}}$ receptor in pcDNA3.1+ (Guthrie DNA Resource Center, Sayre, PA) using $3 \mu \mathrm{g}$ of DNA for every dish and the Lipofectamine Plus Reagent (Invitrogen, Frederick, MD).

Inositol Phosphate Accumulation Assay. Assays were performed as described previously (Berg et al., 1994; Shi et al., 2007). In brief, cells were seeded in 24-well plates at the density of 40,000/well. Cells were treated with vehicle or $300 \mathrm{nM}$ olanzapine and labeled with $0.5 \mu \mathrm{Ci}\left[{ }^{3} \mathrm{H}\right]$ myoinositol/well for $24 \mathrm{~h}$ in serum-free Dulbecco's modified Eagle's medium. Cells were washed with Hank's balanced salt solution containing $20 \mathrm{mM} \mathrm{LiCl}_{2}$ and $20 \mathrm{mM} \mathrm{HEPES,} \mathrm{pH} \mathrm{7.4.}$ Phosphoinositol hydrolysis was initiated with the addition of DOI at $37^{\circ} \mathrm{C}$. Reaction was stopped after $30 \mathrm{~min}$ with ice-cold $10 \mathrm{mM}$ formic acid. The accumulation of ${ }^{3} \mathrm{H}$-labeled inositol phosphate (IP) was determined by ion exchange chromatography.

Statistics. All statistical analyses were performed using the GBSTAT School Pack (Dynamic Microsystems, Silver Spring, MD). Data are expressed as means \pm S.E.M. For Western blots and the IP accumulation assay, data were analyzed using a Student's $t$ test for equal variances.

\section{Results}

IP Accumulation Assay. Agonist-stimulated IP accumulation can be used to monitor desensitization of $5-\mathrm{HT}_{2 \mathrm{~A}}$ receptor mediated signaling (Hanley and Hensler, 2002). Treatment with $300 \mathrm{nM}$ olanzapine for $24 \mathrm{~h}$ significantly decreased $(p<0.05)$ DOI $\left(10^{-4} \mathrm{M}\right)$-stimulated IP accumulation by $28 \pm 1.9 \%$ compared with vehicle ( $20 \%$ acetic acid)treated cells (Fig. 1). This decrease suggests a desensitization of $5-\mathrm{HT}_{2 \mathrm{~A}}$-mediated receptor signaling by olanzapine. The DOI concentration was chosen based on the previous doseresponse experiments conducted in our laboratory (Shi et al., 2007).

Olanzapine Induced Phosphorylation of JAK Kinase. Guillet-Deniau et al. (1997) have shown that serotonin stimulation of $5-\mathrm{HT}_{2 \mathrm{~A}}$ receptors causes phosphorylation of JAK2 kinase and association of the receptor with JAK2. To investigate whether olanzapine causes JAK2 phosphorylation, lysates of cytosol and membrane fractions prepared from vehicle (20\% acetic acid)- and olanzapine (300 nM)treated cells were examined by Western blot with anti-phospho-JAK2 antibody, then stripped and reprobed with antiJAK2 antibody (Fig. 2A). Tyrosine phosphorylation of JAK2 was significantly increased $(p<0.05)$ to more than $232 \pm$ $15 \%$ of the control levels in the membrane fraction of olanzapine-treated cells, whereas total JAK2 protein levels did not show any appreciable change.

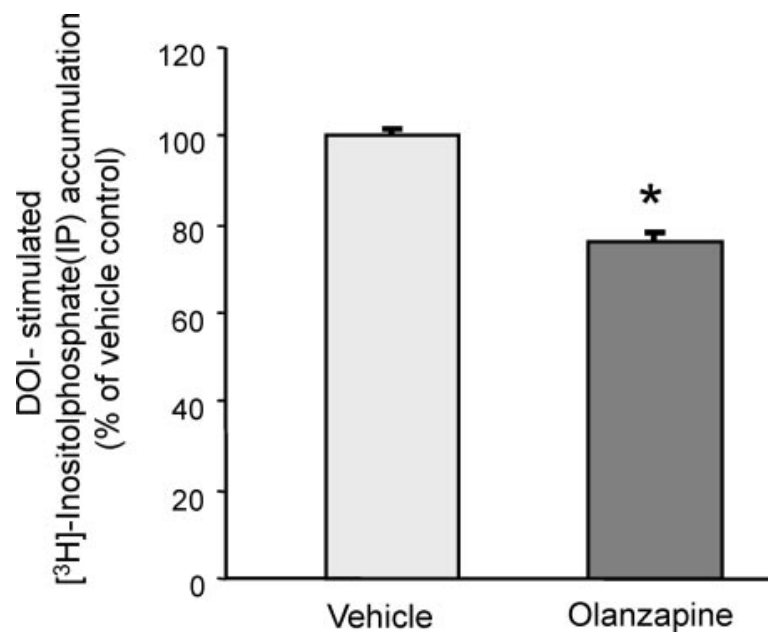

Fig. 1. Olanzapine decreases DOI-stimulated IP accumulation. A1A1v cells were treated either with vehicle (20\% acetic acid) or olanzapine (300 $\mathrm{nM})$ for $24 \mathrm{~h}$ and incubated with $\left[{ }^{3} \mathrm{H}\right]$ myoinositol for the same 24 -h period. Both vehicle- and olanzapine-treated cells were stimulated with $10^{-4} \mathrm{M}$ DOI. Bar graph, mean DOI-stimulated IP accumulation normalized to DOI-stimulated IP accumulation in vehicle-treated cells from three independent experiments. IP accumulation was significantly decreased in olanzapine-treated cells compared with vehicle-treated cells. $*$, significantly different from vehicle-treated cells at $p<0.05$.

Phosphorylation and Nuclear Translocation of STAT Proteins. Phosphorylated JAK2 facilitates activation of various STAT proteins. Tyrosine-phosphorylated STATs then undergo dimerization, translocate to the nucleus, and bind to the target DNA sequences. However, different STAT proteins mediate signaling cascades stimulated by different agonists. To determine which STAT protein(s) are activated in response to olanzapine, lysates of cytosolic and nuclear fractions from control (20\% acetic acid)- and olanzapine (300 $\mathrm{nM}$ )-treated cells were analyzed by Western blot with antiphospho-STAT1, STAT3, and STAT5 antibodies, then stripped and reprobed with corresponding anti-STAT antibodies. We found that phosphorylation and nuclear translocation of STAT3 was significantly increased to $171 \pm 25 \%$ in the olanzapine-treated cells compared with vehicle-treated cells (Fig. 2B), whereas phosphorylation and nuclear translocation of STAT1 and STAT5 did not show any change (data not shown).

Olanzapine Increases RGS7 Protein Levels. To monitor the changes in RGS7 protein levels, lysates from cytosol and membrane fractions of vehicle (20\% acetic acid)- and olanzapine (300 $\mathrm{nM})$-treated cells were analyzed by Western blot with anti-RGS7 antibody (Fig. 3A). We found that RGS7 protein levels were increased in the membrane fraction to $160 \pm 18 \%$ of control levels and significantly increased in cytoplasmic fraction by $193 \pm 32 \%$ of control levels in olanzapine-treated cells compared with vehicle-treated control cells.

Characterization of $\mathbf{5 - H T} \mathbf{H A}_{\mathbf{2 A}}$ Receptor Antibody. A1A1v cells were used to verify the specificity of the $5-\mathrm{HT}_{2 \mathrm{~A}}$ receptor antibody. On Western blots prepared with A1A1v cell lysates, there was a prominent band with a molecular mass of approximately $42 \mathrm{kDa}$ (Fig. 3B). This is very similar to the size of the band produced by in vitro transcription and translation of the human $5-\mathrm{HT}_{2 \mathrm{~A}}$ receptor construct provided by the Guthrie cDNA Resource Center. Overexpression of the human $5-\mathrm{HT}_{2 \mathrm{~A}}$ receptor construct in $\mathrm{A} 1 \mathrm{~A} 1 \mathrm{v}$ cells resulted in 
A
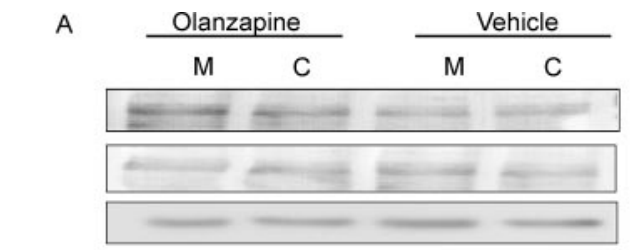

PJAK2

JAK2

Actin

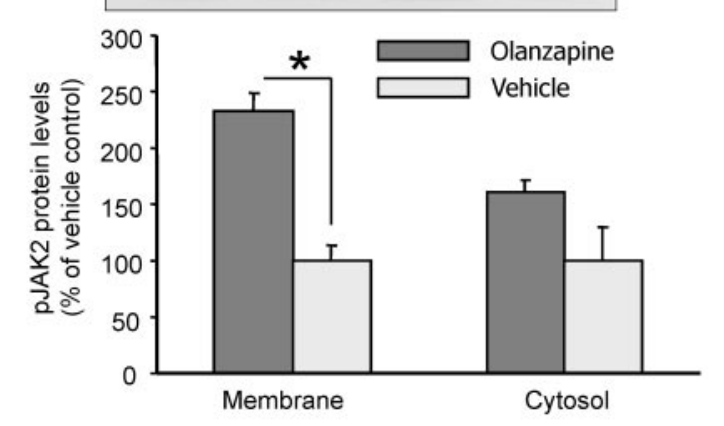

B

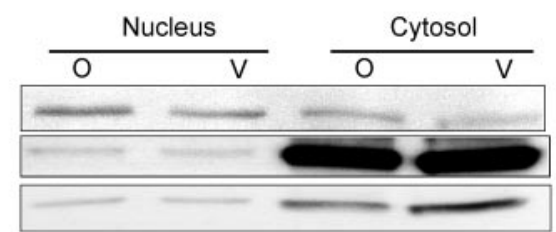

pSTAT3

STAT3

Actin

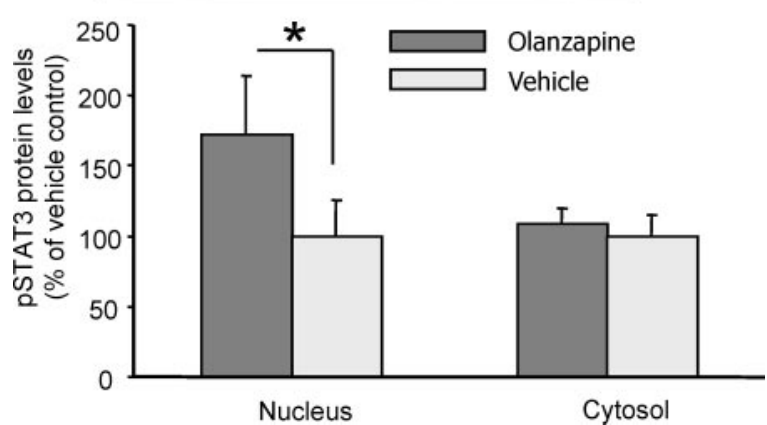

Nucleus

Cytosol

Fig. 2. Olanzapine activates the JAK-STAT signaling cascade. A1A1v cells were treated either with vehicle $(20 \%$ acetic acid) or $(300 \mathrm{nM})$ olanzapine for $24 \mathrm{~h}$. A, cytosol (C) and membrane (M) fractions of cells were analyzed by Western blot with an anti-phospho-JAK2 antibody, stripped, and reprobed with anti-JAK2 and anti-actin antibodies. Bar graph, quantification of phospho-JAK2 protein levels divided by JAK2 protein levels from three independent experiments. Phosphorylation of JAK2 was significantly $(*, p<0.05)$ increased with olanzapine treatment compared with vehicle-treated cells. B, cytosol and nuclear fractions of cells were analyzed by Western blot with anti-phospho-STAT3 antibody, stripped, and reprobed with anti-STAT3 and anti-actin antibodies. Bar graph, quantification of phospho-STAT3 protein levels divided by STAT3 protein levels from three independent experiments. Olanzapine $(\mathrm{O})$ treatment significantly increases the phospho-STAT3 in the nucleus compared with vehicle $(\mathrm{V})$ treatment. $*$, significantly different from vehicle-treated cells at $p<0.05$.

a more intense protein band detected on Western blots prepared with the $5-\mathrm{HT}_{2 \mathrm{~A}}$ receptor antibody (Fig. 3B). Preadsorption control experiments were also performed to verify the specificity of the antibody. Using homogenates from rat frontal cortex and lysates from A1A1v cells transfected with the human $5-\mathrm{HT}_{2 \mathrm{~A}}$ receptor, the $42-\mathrm{kDa}$ band $5-\mathrm{HT}_{2 \mathrm{~A}}$ receptor band was no longer present in the Western blots prepared with the antibody preincubated with the peptide antigen (Fig. 3C). These experiments also demonstrate that the antibody produced, using a peptide based on the sequence for rat $5-\mathrm{HT}_{2 \mathrm{~A}}$ receptor, cross-reacts with the human $5-\mathrm{HT}_{2 \mathrm{~A}}$ receptor expressed in rat cells. Furthermore, the $5-\mathrm{HT}_{2 \mathrm{~A}}$

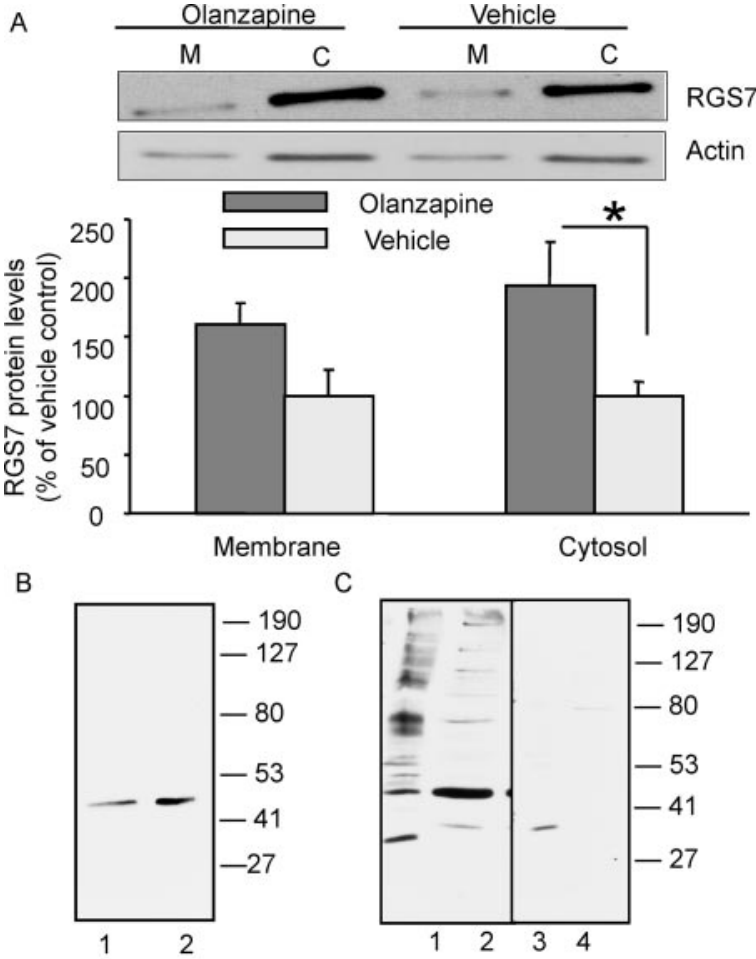

D
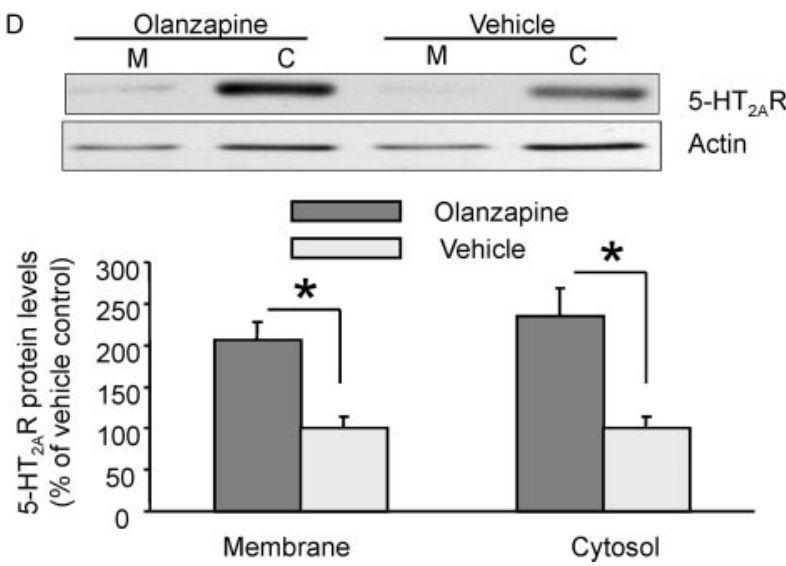

Fig. 3. Olanzapine treatment increases the levels of RGS7 protein and $5-\mathrm{HT}_{2 \mathrm{~A}}$ receptor $\left(5-\mathrm{HT}_{2 \mathrm{~A}} \mathrm{R}\right)$ protein levels. A, A1A1v cells were treated with either vehicle $(20 \%$ acetic acid) or $300 \mathrm{nM}$ olanzapine for $24 \mathrm{~h}$. Cytosol (C) and membrane (M) fractions of cells were analyzed by Western blot with anti-RGS7 antibody, stripped, and reprobed with an antiactin antibody as a loading control. Bar graph, quantification of RGS7 protein levels divided by actin protein levels from three independent experiments. Protein levels of RGS7 were significantly $(*, p<0.05)$ increased in olanzapine-treated cells compared with vehicle-treated cells. $\mathrm{B}, \mathrm{A} 1 \mathrm{~A} 1 \mathrm{v}$ cells transfected with human $5-\mathrm{HT}_{2 \mathrm{~A}}$ receptor (lane 2) produced a larger band than untransfected cells (lane 1) probed by $5-\mathrm{HT}_{2 \mathrm{~A}}$ receptor antibody. C, preabsorption of the $5-\mathrm{HT}_{2 \mathrm{~A}}$ receptor antibody blocked the production of the $42-\mathrm{kDa}$ protein band for $5-\mathrm{HT}_{2 \mathrm{~A}}$ receptor. Western blots prepared with homogenates of rat frontal cortex (lanes 1 and 3) and with lysates of $\mathrm{A} 1 \mathrm{~A} 1 \mathrm{v}$ cells transfected with human $5-\mathrm{HT}_{2 \mathrm{~A}}$ receptor (lanes 2 and 4) were incubated with $5-\mathrm{HT}_{2 \mathrm{~A}}$ receptor antibody (lanes 1 and 2) or $5-\mathrm{HT}_{2 \mathrm{~A}}$ receptor antibody preadsorbed with the peptide antigen (lanes 3 and 4$)$. D, A1A1v cells were treated with either vehicle (20\% acetic acid) or $300 \mathrm{nM}$ olanzapine for $24 \mathrm{~h}$. Cytosol and membrane fractions of cells were analyzed by Western blot with anti-5- $\mathrm{HT}_{2 \mathrm{~A}}$ antibody, stripped, and reprobed with anti-actin antibody as a loading control. Bar graph, quantification of 5- $\mathrm{HT}_{2 \mathrm{~A}}$ protein levels divided by actin protein levels from four independent experiments. $5-\mathrm{HT}_{2 \mathrm{~A}}$ protein levels in both cytosol and membrane fractions were significantly increased in olanzapine-treated cells compared with vehicle-treated cells. *, significantly different from vehicle-treated cells at $p<0.05$. 
receptor antibody cross-reacts with the rat $5-\mathrm{HT}_{2 \mathrm{~A}}$ receptor expressed in a rat cortical cell line.

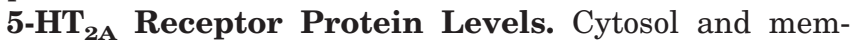
brane fractions from vehicle (20\% acetic acid)- and olanzapine $(300 \mathrm{nM})$-treated cells were analyzed by Western blot with the anti-5- $\mathrm{HT}_{2 \mathrm{~A}}$ antibody we generated. We found a significant increase $(p<0.05)$ in $5-\mathrm{HT}_{2 \mathrm{~A}}$ receptor protein levels in both cytoplasmic (234 $\pm 32 \%$ of control level) and membrane fractions ( $206 \pm 14 \%$ of control levels) of olanzapine-treated cells compared with vehicle-treated cells (Fig. 3D). We also assessed the purity of our membrane fraction after stripping and reprobing the same blot with an anti$\mathrm{NA}^{+}-\mathrm{K}^{+}$-ATPase antibody. A band corresponding to $\mathrm{NA}^{+}$$\mathrm{K}^{+}$-ATPase was mainly present in membrane fraction (data not shown).

JAK Inhibition. A JAK kinase inhibitor, AG490, was used to investigate whether inhibition of the JAK-STAT signaling cascade could reverse the increase of $5-\mathrm{HT}_{2 \mathrm{~A}}$ receptor or RGS7 protein levels observed in response to olanzapine treatment. Cells were treated for $1 \mathrm{~h}$ with 0,15 , and $30 \mu \mathrm{M}$ AG 490 before adding either vehicle or olanzapine. Twentyfour hours later, cells were lysed, and protein levels of phospho-JAK2, RGS7, and phospho-STAT3 were analyzed by Western blot. Olanzapine-induced phosphorylation of JAK2 was decreased with AG490 as shown in Fig. 4A. There was no change in the total JAK2 protein levels. With AG490 treatment, there was a similar decrease in olanzapine-induced STAT3 phosphorylation in the nuclear fraction as shown in Fig. 4B and no change in STAT levels, again confirming previous findings that activation of JAK2 causes phosphorylation and nuclear localization of STAT3.

If the JAK-STAT signaling cascade is mediating the olanzapine-induced increase in protein levels, then inhibiting this signaling cascade should prevent the increase in $5-\mathrm{HT}_{2 \mathrm{~A}}$ receptor and RGS7 protein levels. To test this hypothesis, membrane fractions from vehicle- and olanzapine-treated cells pretreated with AG490 were analyzed by Western blot for $5-\mathrm{HT}_{2 \mathrm{~A}}$ receptor and RGS7 protein levels. As in a previous experiment (Fig. 3A), olanzapine treatment for $24 \mathrm{~h}$ increased the levels of RGS7 protein (Fig. 5, A and B). Treatment with AG490 reduced the olanzapine-induced increase in RGS7 protein in the membrane fractions to the levels in the vehicle-treated cells (Fig. 5A). Treatment with AG490 alone had no effect on the levels of RGS7 protein. Although we observed a similar increase in levels of $5-\mathrm{HT}_{2 \mathrm{~A}}$ receptor protein in olanzapine-treated cells compared with vehicletreated cells as shown before in Fig. 3D, AG490 pretreatment did not alter protein levels of $5-\mathrm{HT}_{2 \mathrm{~A}}$ receptor in cells treated with olanzapine (Fig. 5, C and D), suggesting that the increases in levels are not mediated by the JAK-STAT signaling cascade.

\section{Discussion}

This study demonstrates the involvement of an intracellular signaling cascade, the JAK-STAT pathway, in increasing the levels of RGS7 protein in response to treatment with olanzapine. The increased levels of RGS7 protein in turn could contribute to the desensitization of $5-\mathrm{HT}_{2 \mathrm{~A}}$ receptor signaling induced by olanzapine in A1A1v cells by directly interacting with $\mathrm{G} \alpha_{\mathrm{q} / 11}$ and accelerating GTP hydrolysis. In contrast, we found an increase in $5-\mathrm{HT}_{2 \mathrm{~A}}$ receptor protein
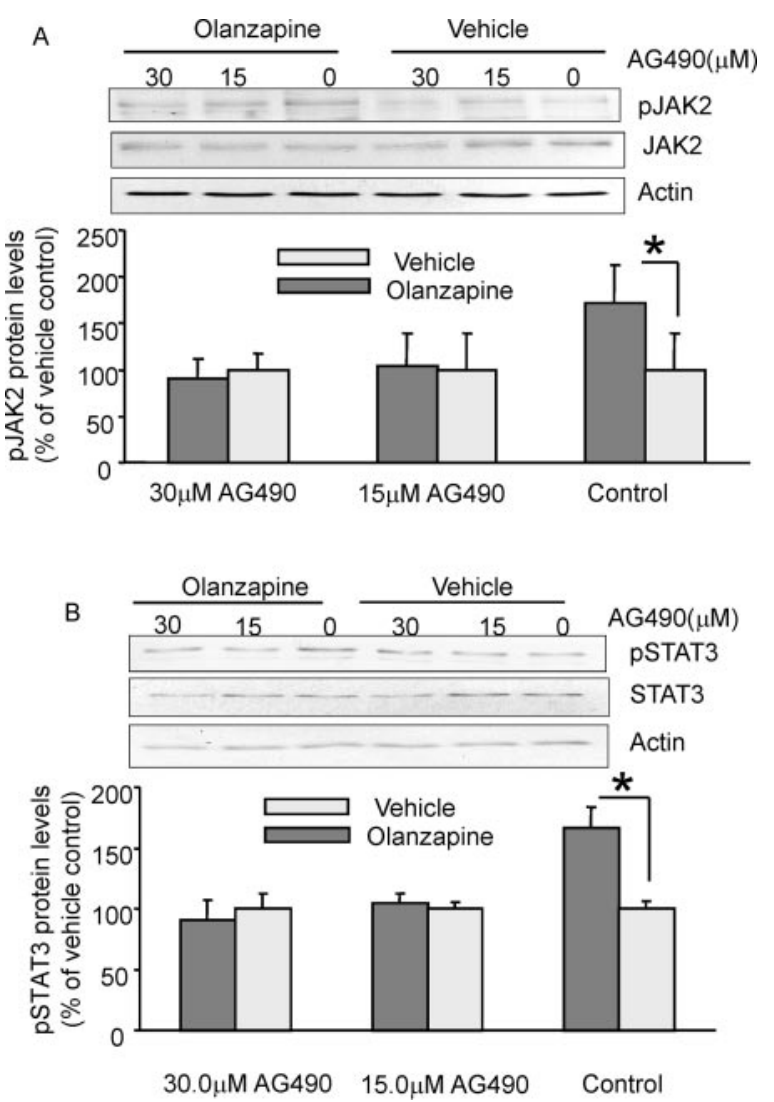

Fig. 4. AG490 pretreatment inhibited olanzapine-induced increases in JAK-STAT signaling. A1A1v cells were pretreated for $1 \mathrm{~h}$ with the indicated concentrations of AG490 before treating with either vehicle (20\% acetic acid) or $300 \mathrm{nM}$ olanzapine for $24 \mathrm{~h}$. A, membrane fraction of cells was analyzed by Western blot with anti-phospho-JAK2 antibody. Blots were stripped and reprobed with anti-JAK2 and anti-actin antibodies. Bar graph, quantification of phospho-JAK2 protein levels divided by JAK2 protein levels from three independent experiments. B, nuclear fractions were analyzed by Western blot with anti-phospho-STAT3 antibodies, stripped, and reprobed with anti-STAT3 and anti-actin antibodies. Bar graph, quantification of phospho-STAT3 protein levels divided by STAT3 protein levels from three independent experiments. AG490 pretreatment decreases phospho-JAK2 levels and phospho-STAT3 nuclear translocation in olanzapine-treated cells compared with cells treated with olanzapine and the AG490 vehicle. *, significantly different from vehicletreated cells at $p<0.05$.

levels with olanzapine treatment that was not associated with increased activation of the JAK-STAT signaling cascade. The increase in $5-\mathrm{HT}_{2 \mathrm{~A}}$ receptor protein levels would not probably contribute to the desensitization response but could conceivably counter or moderate the desensitization response.

Olanzapine and other antipsychotics have been recently reported to stimulate other signaling cascades, including increased phosphorylation of ERK1/2 in rat frontal cortex (Fumagalli et al., 2006) and increased phosphorylation of Akt/PKB and p38 in PC12 cells (Lu et al., 2004). The increased activation of signaling cascades induced by antipsychotics suggests that changes in gene expression regulated by these cascades could contribute to the positive therapeutic benefits seen in schizophrenic patients.

Several microarray studies have explored the effects of olanzapine and other antipsychotics on gene expression, reporting changes in expression of a host of genes including RGS proteins, and gene families linked with synaptic plas- 

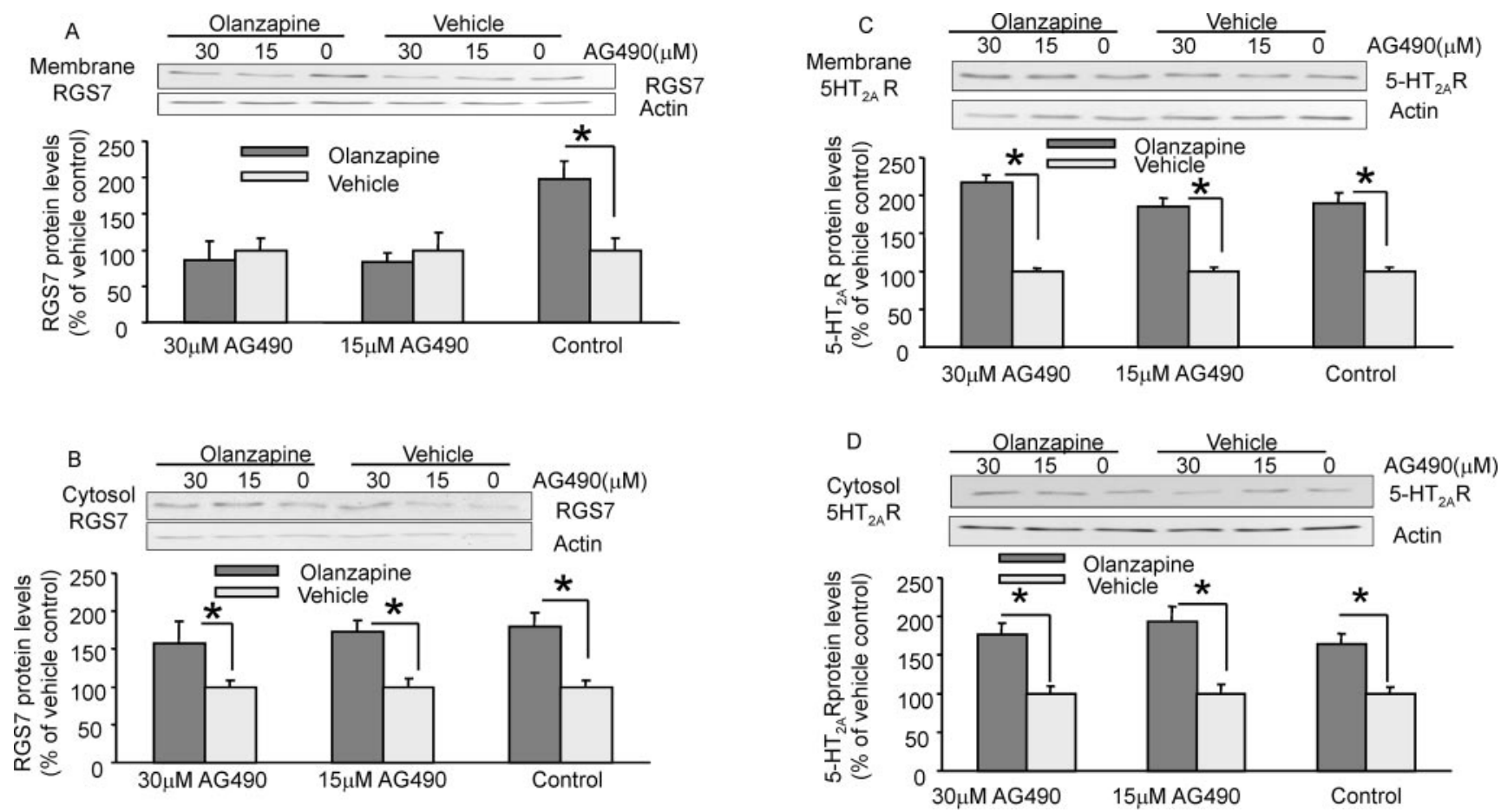

Fig. 5. AG490 pretreatment reduces the olanzapine-induced increase in RGS7 protein levels in membrane but not the levels of $5 \mathrm{HT}_{2 \mathrm{~A}}$ receptor protein $\left(5-\mathrm{HT}_{2 \mathrm{~A}} \mathrm{R}\right)$. A1A1v cells were pretreated with the indicated concentrations of AG490 for $1 \mathrm{~h}$ before treating with either vehicle (20\% acetic acid) or 300 $\mathrm{nM}$ olanzapine for $24 \mathrm{~h}$. The membrane (A) and cytosol fraction (B) of cells were analyzed by Western blot with anti-RGS7 antibody, stripped, and reprobed with anti-actin antibody; actin was used as a loading control. Bar graph, quantification of RGS7 protein levels divided by actin protein levels from three independent experiments. Membrane (C) and cytosol fractions (D) of cells were analyzed by Western blot with anti-5-HT WA $_{2}$ receptor antibody, stripped, and reprobed with anti-actin antibody as a loading control. Pretreatment with AG490 had no effect on the increase in 5-HT $2 A$ receptor protein levels induced by olanzapine. $*$, significantly different from vehicle-treated cells at $p<0.05$.

ticity and presynaptic neurotransmission (Fehér et al., 2005; Fatemi et al., 2006). Fatemi et al. (2006) reported an increase in expression of RGS19 mRNA and a decrease in expression of RGS2 mRNA in the frontal cortex of rats treated for 3 weeks with olanzapine. GAP activity of RGS19 is associated with $\mathrm{G} \alpha_{\mathrm{z}}$, a member of the $\mathrm{G} \alpha_{\mathrm{i} / \mathrm{o}}-\mathrm{G}$ protein family, whereas $5-\mathrm{HT}_{2 \mathrm{~A}}$ receptors are coupled with $\mathrm{G} \alpha_{\mathrm{q} / 11}$ proteins. Therefore, increased RGS19 is unlikely to affect olanzapine-induced desensitization of 5- $\mathrm{HT}_{2 \mathrm{~A}}$ receptor signaling. Although RGS2 protein associates with $\mathrm{G} \alpha_{\mathrm{q}}$ protein and could decrease the $5-\mathrm{HT}_{2 \mathrm{~A}}$ receptor signaling, a decrease in expression of RGS2 protein could not cause the desensitization of $5-\mathrm{HT}_{2 \mathrm{~A}}$ receptor signaling induced by olanzapine because a decrease in RGS protein expression would probably result in increased receptor signaling. Although RGS2 is expressed in the frontal cortex, it is not known if it colocalizes with $5-\mathrm{HT}_{2 \mathrm{~A}}$ receptors in the frontal cortex.

None of these microarray studies identified alterations in RGS7 protein or 5- $\mathrm{HT}_{2 \mathrm{~A}}$ receptor mRNA levels. It is important to remember that changes in mRNA levels may or may not result in changes in protein levels, and changes in protein levels may not be due to changes in mRNA levels. It is also important to emphasize that these studies were conducted in different experimental settings with different time course and dose regimens than our study. Each study highlights important findings, further extending our understanding of the mechanism of action of antipsychotics. It is becoming evident that there could be numerous pathways and alterations in gene expression that lead to the development of psychosis (Ko et al., 2006) and its treatment with atypical antipsychotics.
Genetic risk factors for schizophrenia are beginning to be identified and include RGS4 protein with RGS4 protein expression being reduced in the frontal cortex in schizophrenics (Gu et al., 2007). Like RGS7 protein, RGS4 regulates $5-\mathrm{HT}_{2 \mathrm{~A}}$ receptor signaling. Individualized treatment approaches based on a patient's genetic profile are being pioneered in cancer treatment and could be developed for schizophrenia and other mood disorders. For example, olanzapine-induced increases in expression of RGS7 protein could mitigate reductions in RGS4 protein expression in patients with alterations in RGS4. Based on the concept of individualized treatment approaches, it would be important to determine which other atypical antipsychotics increase RGS7 and possibly RGS4 protein expression.

Direct association of JAK2 and STAT3 with $5-\mathrm{HT}_{2 \mathrm{~A}}$ receptors and activation of the JAK-STAT signaling cascade by $5-\mathrm{HT}_{2 \mathrm{~A}}$ receptor agonists has been reported previously (Guillet-Deniau et al., 1997). In the present study, we found JAK2 activation and increased phosphorylation and nuclear localization of phospho-STAT3 in olanzapine-treated cells. It is interesting to note that phosphorylation and nuclear translocation of other isoforms of STAT proteins, STAT1 and STAT5, did not show any change with olanzapine treatment. Activation of STAT proteins, which are transcription factors, could bolster the previous notion that antipsychotic agents affect expression of various genes.

Our experiments with a JAK kinase inhibitor, AG490, suggest that the increased levels of RGS7 protein are mediated by the JAK-STAT signaling cascade in response to olanzapine treatment. Interestingly, AG490 selectively targeted the membrane-localized RGS7 protein and had no effect on 
the levels in cytosol fraction. The overall effect of AG490 is a decrease in the total levels of RGS7 protein (i.e., membrane plus cytosol), suggesting that olanzapine-induced JAK-STAT signaling increases the levels of RGS7 protein rather than causing a redistribution of the protein. We speculate that transcriptional activity of phospho-STAT3 could increase RGS7 mRNA expression and be responsible for increased levels of RGS7 protein in the membrane fraction. The mechanism(s) involved in the selective decrease in the membrane fraction are unknown but could involve a chaperone protein. However, further studies are needed to test these hypotheses. In contrast, changes in $5-\mathrm{HT}_{2 \mathrm{~A}}$ receptor protein levels seem to be regulated by a different mechanism because pretreatment with AG490 fails to reverse the olanzapine-induce increase in receptor protein levels.

Most atypical antipsychotics cause desensitization of $5-\mathrm{HT}_{2 \mathrm{~A}}$ receptor signaling. The decrease in DOI-stimulated IP accumulation with olanzapine treatment in our study is consistent with these findings and supports the use of $\mathrm{A} 1 \mathrm{~A} 1 \mathrm{v}$ cells as a model to study the actions of olanzapine on $5-\mathrm{HT}_{2 \mathrm{~A}}$ receptor signaling. Previous experiments in A1A1v cells using the selective 5- $\mathrm{HT}_{2 \mathrm{~A}}$ receptor antagonist, MDL 100,907, demonstrated that IP accumulation stimulated by the $5-\mathrm{HT}_{2 \mathrm{~A} / 2 \mathrm{C}}$-selective agonist DOI is not likely due to stimulation of $5-\mathrm{HT}_{2 \mathrm{C}}$ receptors (Shi et al., 2007). Numerous investigations have explored the mechanisms by which antipsychotics cause desensitization of $5-\mathrm{HT}_{2 \mathrm{~A}}$ receptor signaling. This desensitization by antipsychotics could be mediated by receptor internalization, uncoupling of $\mathrm{G}$ proteins from receptor, and receptor down-regulation (Roth et al., 1995; Willins et al., 1999) in addition to increases in RGS7 protein.

Other mechanisms have been associated with desensitization of $5-\mathrm{HT}_{2 \mathrm{~A}}$ receptor signaling as a result of treatment with atypical antipsychotics. Several studies specifically investigated changes in the transcript level of $5-\mathrm{HT}_{2 \mathrm{~A}}$ receptors with both short-term and chronic antipsychotic treatments (Burnet et al., 1996; Doat-Meyerhoefer et al., 2005). Buckland et al. (1997) reported a significant decrease in receptor mRNA in hippocampus, brain stem, and midbrain, whereas no significant change was observed in other brain regions after 32 days of treatment with the atypical antipsychotic clozapine. However, in the same study, 4 days of clozapine treatment did not produce any significant change, but a trend for a decreased mRNA expression was observed in major brain areas. As noted previously, changes in mRNA levels do not necessarily result in corresponding changes in protein levels, so changes in $5-\mathrm{HT}_{2 \mathrm{~A}}$ receptor mRNA levels are not necessarily inconsistent with the current findings. We found an increase in $5-\mathrm{HT}_{2 \mathrm{~A}}$ receptor protein levels in both the cytosol and membrane fractions. Previous studies reported a sizable amount of $5-\mathrm{HT}_{2 \mathrm{~A}}$ receptors in the cytosol in addition to that found in the membrane (Cornea-Hébert et al., 1999). Several reports suggest a decrease in $B_{\max }$ with no change in $K_{\mathrm{d}}$ after treatment with antipsychotics (Matsubara and Meltzer, 1989; Doat-Meyerhoefer et al., 2005). A decrease in the density of $5-\mathrm{HT}_{2 \mathrm{~A}}$ receptors without any change in affinity is consistent with the receptor internalization previously reported (Roth et al., 1995; Willins et al., 1998). An increase in $5-\mathrm{HT}_{2 \mathrm{~A}}$ receptor protein levels in the cytosol, as we found with Western blot analysis, could reflect internalized receptors. Furthermore, an increase in total $5-\mathrm{HT}_{2 \mathrm{~A}}$ receptor protein levels is not necessarily inconsistent with a decrease in receptor density. $5-\mathrm{HT}_{2 \mathrm{~A}}$ receptor proteins undergo extensive post-translational modifications that could affect ligand binding. It is difficult to speculate at this point about the post-translational modifications that are required for or inhibit ligand binding. It is likely that multiple mechanisms contribute to desensitization of $5-\mathrm{HT}_{2 \mathrm{~A}}$ receptor signaling and that the specific mechanisms involved are probably tissue-specific.

In summary, our in vitro data highlight a new role of JAK-STAT signaling in treatment with olanzapine. Increased activation of this pathway by olanzapine increases expression of RGS7 protein. Increased RGS7 protein could directly contribute to the desensitization of $5-\mathrm{HT}_{2 \mathrm{~A}}$ receptor signaling by accelerating hydrolysis of GTP-bound $\mathrm{G} \alpha$ q protein. Unfortunately, the JAK inhibitor AG490 interferes with the IP accumulation assay and therefore precludes our ability to determine whether JAK-STAT signaling contributes to the desensitization of $5-\mathrm{HT}_{2 \mathrm{~A}}$ receptors in our model system. We are further investigating whether increased RGS7 protein is the result of increased transcriptional activity and whether blocking membrane localization of RGS7 protein inhibits desensitization of $5-\mathrm{HT}_{2 \mathrm{~A}}$ receptor signaling cascade. Further studies are also needed in animal models to confirm these findings in vivo. Overall, the results from this study provide a further understanding of possible involvement of intracellular pathways in mediating the effects of atypical antipsychotics.

\section{References}

Andrews NC and Faller DV (1991) A rapid micropreparation technique for extraction of DNA-binding proteins from limiting numbers of mammalian cells. Nucleic Acids Res 19:2499.

Banes AK, Shaw SM, Tawfik A, Patel BP, Ogbi S, Fulton D, and Marrero MB (2005) Activation of the JAK/STAT pathway in vascular smooth muscle by serotonin. Am J Physiol 288:C805-C812.

Berg KA, Clarke WP, Sailstad C, Saltzman A, and Maayani S (1994) Signal transduction differences between 5-hydroxytryptamine type $2 \mathrm{~A}$ and type $2 \mathrm{C}$ receptor systems. Mol Pharmacol 46:477-484.

Berg KA, Stout BD, Maayani S, and Clarke WP (2001) Differences in rapid desensitization of 5-hydroxytryptamine $2 \mathrm{~A}$ and 5-hydroxytryptamine $2 \mathrm{C}$ receptormediated phospholipase C activation. J Pharmacol Exp Ther 299:593-602.

Bhat GJ, Thekkumkara TJ, Thomas WG, Conrad KM, and Baker KM (1994) Angiotensin II stimulates Sis-inducing factor-like DNA binding activity: evidence that the AT1A receptor activates transcription factor-Stat91 and/or a related protein. $J$ Biol Chem 269:31443-31449.

Buckland PR, D'Souza U, Maher NA, and McGuffin P (1997) The effects of antipsychotic drugs on the mRNA levels of serotonin 5HT2A and 5HT2C receptors. Brain Res Mol Brain Res 48:45-52.

Burnet PW, Eastwood SL, and Harrison PJ (1996) 5-HT1A and 5-HT2A receptor mRNAs and binding site densities are differentially altered in schizophrenia Neuropsychopharmacology 15:442-455.

Cornea-Hébert V, Riad M, Wu C, Singh SK, and Descarries L (1999) Cellular and subcellular distribution of the serotonin 5-HT2A receptor in the central nervous system of adult rat. J Comp Neurol 409:187-209.

Darnell JE Jr (1997) STATs and gene regulation. Science 277:1630-1635.

DiBello PR, Garrison TR, Apanovitch DM, Hoffman G, Shuey DJ, Mason K, Cockett MI, and Dohlman HG (1998) Selective uncoupling of RGS action by a single point mutation in the G protein alpha-subunit. J Biol Chem 273:5780-5784.

Doat-Meyerhoefer MM, Hard R, Winter JC, and Rabin RA (2005) Effects of clozapine and 2,5-dimethoxy-4-methylamphetamine [DOM] on 5-HT2A receptor expression in discrete brain areas. Pharmacol Biochem Behav 81:750-757.

Fatemi SH, Reutiman TJ, Folsom TD, Bell C, Nos L, Fried P, Pearce DA, Singh S, Siderovski DP, Willard FS, et al. (2006) Chronic olanzapine treatment causes differential expression of genes in frontal cortex of rats as revealed by DNA microarray technique. Neuropsychopharmacology 31:1888-1899.

Fehér LZ, Kalman J, Puskas LG, Gyulveszi G, Kitajka K, Penke B, Palotas M, Samarova EI, Molnar J, Zvara A, et al. (2005) Impact of haloperidol and risperidone on gene expression profile in the rat cortex. Neurochem Int 47:271-280.

Fumagalli F, Frasca A, Sparta M, Drago F, Racagni G, and Riva MA (2006) Longterm exposure to the atypical antipsychotic olanzapine differently up-regulates extracellular signal-regulated kinases 1 and 2 phosphorylation in subcellular compartments of rat prefrontal cortex. Mol Pharmacol 69:1366-1372.

Garlow SJ, Morilak DA, Dean RR, Roth BL, and Ciaranello RD (1993) Production and characterization of a specific 5-HT2 receptor antibody. Brain Res 615:113120.

Ghavami A, Hunt RA, Olsen MA, Zhang J, Smith DL, Kalgaonkar S, Rahman Z, and Young KH (2004) Differential effects of regulator of G protein signaling (RGS) 
proteins on serotonin 5-HT1A, 5-HT2A, and dopamine D2 receptor-mediated signaling and adenylyl cyclase activity. Cell Signal 16:711-721.

Glennon RA, Titeler M, and McKenney JD (1984) Evidence for 5-HT2 involvement in the mechanism of action of hallucinogenic agents. Life Sci 35:2505-2511.

Gu Z, Jiang Q, and Yan Z (2007) RGS4 modulates serotonin signaling in prefrontal cortex and links to serotonin dysfunction in a rat model of schizophrenia. Mol Pharmacol 71:1030-1039.

Guillet-Deniau I, Burnol AF, and Girard J (1997) Identification and localization of a skeletal muscle serotonin 5-HT2A receptor coupled to the Jak/STAT pathway. $J$ Biol Chem 272:14825-14829.

Hanley NR and Hensler JG (2002) Mechanisms of ligand-induced desensitization of the 5-hydroxytryptamine(2A) receptor. J Pharmacol Exp Ther 300:468-477.

Herrick-Davis K, Grinde E, and Teitler M (2000) Inverse agonist activity of atypical antipsychotic drugs at human 5-hydroxytryptamine2C receptors. J Pharmacol Exp Ther 295:226-232.

Ihle JN (1995) Cytokine receptor signalling. Nature 377:591-594

Ivins KJ and Molinoff PB (1990) Serotonin-2 receptors coupled to phosphoinositide hydrolysis in a clonal cell line. Mol Pharmacol 37:622-630.

Kasper S, Hale A, Azorin JM, and Moller HJ (1999) Benefit-risk evaluation of olanzapine, risperidone and sertindole in the treatment of schizophrenia. Eur Arch Psychiatry Clin Neurosci 249 (Suppl 2):II1-II14.

Ko F, Tallerico T, and Seeman P (2006) Antipsychotic pathway genes with expression altered in opposite direction by antipsychotics and amphetamine. Synapse 60:141151.

Koelle MR and Horvitz HR (1996) EGL-10 regulates G protein signaling in the $C$. elegans nervous system and shares a conserved domain with many mammalian proteins. Cell 84:115-125.

Krumins AM, Barker SA, Huang C, Sunahara RK, Yu K, Wilkie TM, Gold SJ, and Mumby SM (2004) Differentially regulated expression of endogenous RGS4 and RGS7. J Biol Chem 279:2593-2599.

Littrell KH, Petty RG, and Wolf NM (2006) Olanzapine: a 5-year perspective. Expert Rev Neurother 6:811-821.

Lu XH, Bradley RJ, and Dwyer DS (2004) Olanzapine produces trophic effects in vitro and stimulates phosphorylation of Akt/PKB, ERK1/2, and the mitogenactivated protein kinase P38. Brain Res 1011:58-68.
Lucaites VL, Nelson DL, Wainscott DB, and Baez M (1996) Receptor subtype and density determine the coupling repertoire of the 5-HT2 receptor subfamily. Life Sci 59:1081-1095.

Matsubara S and Meltzer HY (1989) Effect of typical and atypical antipsychotic drugs on 5-HT2 receptor density in rat cerebral cortex. Life Sci 45:1397-1406.

Meltzer HY, Park S, and Kessler R (1999) Cognition, schizophrenia, and the atypical antipsychotic drugs. Proc Natl Acad Sci U S A 96:13591-13593.

Rauser L, Savage JE, Meltzer HY, and Roth BL (2001) Inverse agonist actions of typical and atypical antipsychotic drugs at the human 5-hydroxytryptamine $(2 \mathrm{C})$ receptor. J Pharmacol Exp Ther 299:83-89.

Roth BL, Palvimaki EP, Berry S, Khan N, Sachs N, Uluer A, and Choudhary MS (1995) 5-Hydroxytryptamine2A (5-HT2A) receptor desensitization can occur without down-regulation. J Pharmacol Exp Ther 275:1638-1646.

Roy AA, Nunn C, Ming H, Zou MX, Penninger J, Kirshenbaum LA, Dixon SJ, and Chidiac P (2006) Up-regulation of endogenous RGS2 mediates cross-desensitization between Gs and Gq signaling in osteoblasts. $J$ Biol Chem 281:32684-2693

Shi J, Zemaitaitis B, and Muma NA (2007) Phosphorylation of Galpha11 protein contributes to agonist-induced desensitization of 5-HT2A receptor signaling. Mo Pharmacol 71:303-313.

Tucker RP (2004) Neural crest cells: a model for invasive behavior. Int J Biochem Cell Biol 36:173-177.

Willins DL, Alsayegh L, Berry SA, Backstrom JR, Sanders-Bush E, Friedman L, Khan N, and Roth BL (1998) Serotonergic antagonist effects on trafficking of serotonin 5-HT2A receptors in vitro and in vivo. Ann N Y Acad Sci 861:121-127.

Willins DL, Berry SA, Alsayegh L, Backstrom JR, Sanders-Bush E, Friedman L, and Roth BL (1999) Clozapine and other 5-hydroxytryptamine-2A receptor antagonists alter the subcellular distribution of 5-hydroxytryptamine-2A receptors in vitro and in vivo. Neuroscience 91:599-606.

Zhang JH and Simonds WF (2000) Copurification of brain G-protein beta5 with RGS6 and RGS7. J Neurosci 20:RC59.

Address correspondence to: Dr. Nancy A. Muma, Department of Pharmacology and Toxicology, School of Pharmacy, University of Kansas, 1251 Wescoe Hall Drive, 5064 Malott Hall, Lawrence, KS 66045. E-mail: nmuma@ku.edu 